\title{
IMMEDIATE AND DELAYED HYPERSENSITIVITY REACTIONS TO LATEX GLOVES IN A DENTAL STUDENT. A case report.
}

Iliyana Stoeva

Department of Allergology, Physiotherapy and Clinical radiology,

Faculty of Dental Medicine, Medical University-Plovdiv, Bulgaria

\section{ABSTRACT:}

The article presents a case of dental student with immediate and delayed hypersensitivity reaction to latex gloves. Symptoms appeared during the second year of regularly using of latex gloves. The student was with no history of allergies and no previous exposure to latex products.

Key words: natural rubber latex, gloves, rubber additives hypersensitivity.

Dental students are exposed to many skin irritants and allergens (2). Some of them penetrate easy through the gloves (4). Latex gloves may cause immediate or contact allergy or they may cause irritant reactions (1). The adverse reactions to latex gloves affect usually skin hand but also noncutaneous reactions occur (5).

A 25-year-old dental student with a history of skin hand complaints using latex gloves was referred to sector of Dental Allergy in Faculty of Dental Medicine, Plovdiv (Fig. 1).

During clinical practice in Faculty of Dental Medicine, she used powder latex gloves, the only available for dental students. She was using latex gloves regularly from semester 7 . The symptoms appeared during semester 9 . She reported an improvement during examinations when the contact with latex gloves was absent.

She had no history of atopy or food allergy.

The student was tested for latex allergy with commercial product of Stallergenes, France. The skin prick test to latex was $4 \mathrm{~mm}$. She was also patch test to Swedish dental stuff series (Chemotechnique Diagnostics, Sweden) and to rubber additive components - Thiuram mix, Mercaptomix, N-isopropyl-N-phenyl-4-phenylenediamine (Chemotechnique Diagnostics, Sweden). She developed a positive reaction (++) to Thiuram mix and Mercaptomix. No reaction was registered for Swedish dental stuff series.

She changed the type of gloves. Once she avoided wearing latex gloves the symptoms of hand eczema improved (Fig. 2).

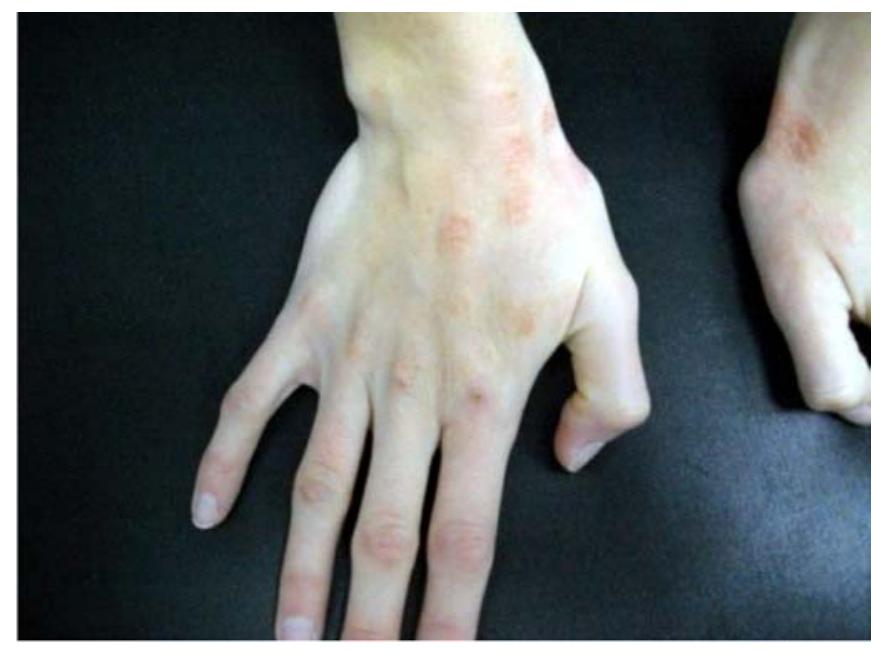

Fig. 1. Skin symptoms associated with latex gloves use.

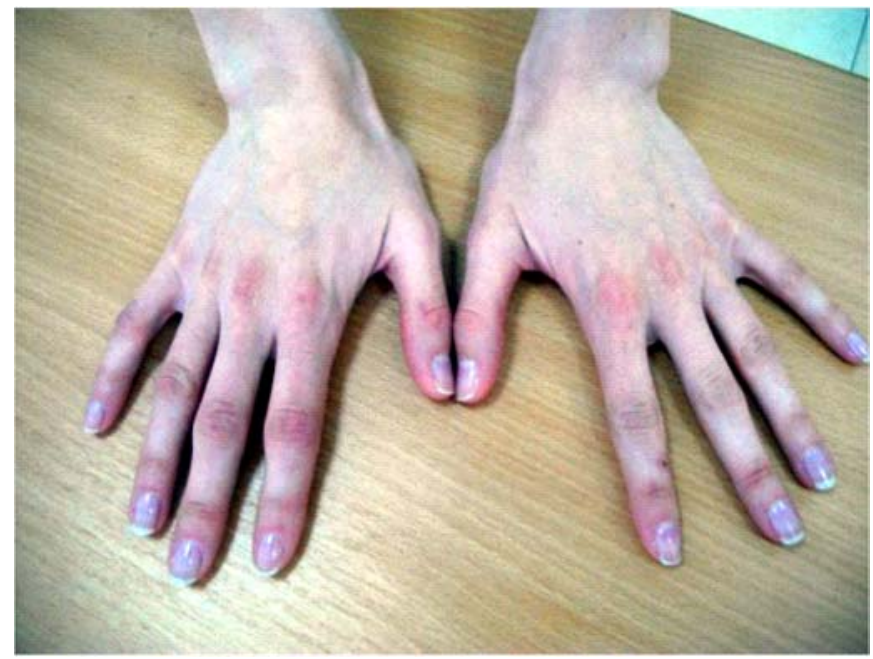

Fig. 2. Improvement of skin symptoms after changing latex gloves with latex free gloves. 


\section{Discussion}

Such localized skin reactions, manifested only during dental clinical practice, may be attributed to a wide variety of possible occupational causes - NRL protein allergy, allergic contact dermatitis and irritant dermatitis, which may manifest with similar symptoms $(1,3)$. The skin hand problem of our patient was due to contact with latex gloves. She reacted not only to latex allergen but also to other chemicals in latex gloves. These reactions may be associated with allergy to acrylates or disinfectants, which penetrate easy through the latex gloves (4), but no reaction to allergens from Swedish dental stuff series was observed.

The absence of history of previous latex exposure, atopy and food allergy leads that occupational exposure to latex gloves provoked the sensitization.

\section{REFERENCES:}

1. The dental team and latex hypersensitivity. ADA Council on Scientific Affairs. J Am Dent Assoc. 1999 Feb;130(2):257-264. [No authors listed] [PubMed]

2. Hamann CP, Rodgers PA, Sullivan KM. Occupational allergens in dentistry. Curr Opin Allergy Clin Immunol. 2004 Oct;4(5):403-409 [PubMed]
3. Hamann CP, Kick SA. Update: Immediate and delayed hypersensitivity to natural rubber latex. Cutis cutaneous medicine for the practitioner. 1993 Nov;52(5):307-311. [PubMed]

4. Munksgaard, E.C. Permeability of protective gloves to (di)methacrylates in resinous dental materials. Scand J Dent Res. 1992 Jun;100(3):189-192. doi.: 10.1111/j.1600-0722.1992.tb01739.x [PubMed]

5. Tarlo SM, Sussman GL, Holness DL. Latex sensitivity in dental students and staff: A cross-sectional study. J Allergy Clin Immunol, 1997 Mar;99(3):396-401. doi:10.1016/S0091-6749(97)70058-7 [PubMed]

\author{
Adrress for correspondence: \\ Iliyana Stoeva \\ Department of Allergology, Phisiotherapy and Clinical Radiology, Faculty of Dental \\ Medicine, Medical University - Plovdiv \\ 3, Hristo Botev Blvd., 4000 Plovdiv, Bulgaria \\ E-mail: stoeva_iliana@abv.bg
}

